\title{
Quality Assessment of Indian Universities: An Analytical Study of NAAC Accreditation Scores
}

\author{
${ }^{1}$ Ravikumar K, \\ Research Scholar, Kalinga Institute of Industrial Technology(KIIT), Bhubaneswar, Odisha, India, Email: ravinaac@gmail.com \\ ${ }^{2}$ Sasmitarani Samanta, \\ Pro-Vice Chancellor, Kalinga Institute of Industrial Technology (KIIT), Bhubaneswar, Odisha, India Email: drsasmita@kiit.ac.in
}

${ }^{3}$ Amiya Kumar Rath,

Adviser, NAAC, Bengaluru, India Email: amiyakumarrath@gmail.com

${ }^{4} \mathrm{~S}$ Srinivasaragavan,

Professor and Head, Department of Library and Information Sciences, Bharathidasan University, Tiruchirappalli, Tamil Nadu, India, Email: maduraiseenoo@yahoo.co.in

\begin{abstract}
This paper reveals that the performance and quality enhancement initiatives of Indian Universities based on the accreditation scores attained through the NAAC assessment process in terms of Criteria wise analysis, Region wise analysis and State wise analysis of Universities have been made. It is observed that average CGPA for the five regions of the country, Southern region is dominant with 3.07, which is followed by North Eastern region Universities with average CGPA of 3.04. Analysis through region wise, the performance of Universities is in the Eastern region is low as per the RAF of NAAC accreditation. Analysis through region wise, It would reveal that among the State Universities, Northern region have got higher score of CGPA (2.94), which is followed by Western region (2.93) and Southern region (2.90).In general observation is that the accredited State Universities are didn't performing well. Since no region would acquire the CGPA of 3.0 and all India CGPA is 2.85 , it shows the dissimilarities among the Universities in terms of performance quality with regard to all criterion. It is quiet surprise to know that the average CGPA of Research, Consultancy, and Extensions (3) is very much low with 2.65 compare with other criterions. Being the Universities, they need to make emphasize on enhancing the quality of research. The largest share of accredited institutions are from Western and Northeastern region. In general, the response from the university sector is better compared to that from the college sector.
\end{abstract}

Keywords: Accreditation, Assessment, Universities, Quality Assurance, NAAC Criteria's

\section{Introduction}

India has one of the largest and diverse education systems in the world. High-quality education is critical when it comes to increasing the professional competence, so that they are equipped to provide high standards. If highquality education is to be achieved globally, the implementation of the education programme needs to be accelerated to ensure that it leads to competency, provides service users with highquality care and access to professionals who can perform to international standards and develop towards a level of excellence. One way to assure quality and accountability in education is through the implementation of a credible, comprehensive and effective accreditation system. The aim of accreditation is to ensure that students graduate at an acceptable level so that they can meet the needs and wider their progression. Once accredited by the relevant government agency, educational institutions can then exercise their power both to award degrees and to license and certify graduates for professional practice. To offer quality education, accreditation and assessment is must for all the higher educational institution. The sector is plagued by a shortage of well-trained faculty, poor infrastructure and outdated and irrelevant curricula. The use of technology in higher education remains limited and standards of research and teaching at Indian Universities are far below international standards with no Indian 
University featured among the top 200 institutions globally.

\section{Review of Literature}

Amutha, S., \& Ponmudiraj, B. S. (2019) The principal aim of Quality Assurance (QA) is Assessment and Accreditation (A\&A). Based on the status of accreditation the stakeholders particularly the students take an informed decision about selection of programmes in a specific Higher Education Institutions (HEIs), viz, a University or a College. This paper presents a symbiotic analysis of Higher Education Institutions (HEIs) accredited by National Assessment and Accreditation Council (NAAC), India.

Mukhopadhyay, P (2018) This paper revealed the various stakeholders use the ranking of Higher Education Institutions (HEIs) as a measure of quality. This is evident from numerous ranking efforts - both of the government (National Institutional Ranking Framework (NIRF) of the Ministry of Human Resources Development (MHRD), the National Academic Accreditation Council (NAAC) and the National Board of Accreditation (NBA) and the private sector. Developing countries like India should assess the academic quality by working with parameters that are globally acceptable, transparent to all stakeholders and not amenable to the control of lobby groups. One such parameter is publications in reputed international journals indexed by databases like Scopus and Web of Science is also considered by the NIRF. In contrary to the NIRF method, this propose that instead of considering the total publications the computations should be based on the publication rate (number of publications per teacher) to control the faculty size bias.

\section{Scope of the Study}

The present study aimed at analyse the performance and quality enhancement initiatives of Indian Universities based on the accreditation scores attained through the NAAC assessment process. Criteria wise analysis, Region wise analysis and State wise analysis of Universities have been made. A comparative analysis of Central and State Universities were also brought out. The outcome of accredited analysis based on NAAC SSR report as per the revised accreditation frame work has been made.

\section{Objectives of the study}

- To suggest post accreditation strategies for the sustenance, enhancement and assurance of quality in the accredited institutions.

- Institutions not achieved a good quality score, this study provide appropriate guidance for up gradation of the quality during the subsequent cycles of Assessment and Accreditation.

- Internal Quality Assurance cell of each institution can get the necessary guidance and direction to pursue the quality parameters to improve their earlier accreditation performance.

- To take the meta-evaluation study and identify the crucial factors of the institutions and the regulatory agencies.

- Government suggests to undertake the policies for reforms and follow up actions by the higher education institutions.

\section{Analysis and Interpretation}

The number of Higher Education Institutions volunteered for Assessment and Accreditation based on the seven criterions Curricular Aspects, Teaching \& Learning, Evaluation, Research, Consultancy, and Extensions, Infrastructure and Learning Resources, Student Support and Progression, Governance, Leadership, and Management, Institutional Values \& Best Practices (C1,C2,C3,C4,C5,C6,\& C7) as evolved by NAAC in its reaccreditation frame work. All of them are not accredited. The number of valid accredited 
Institutions accredited, as on March 2020 out of

the total number are presented below:

\begin{tabular}{|c|c|c|c|}
\hline Types of Universities & $\begin{array}{c}\text { Total of } \\
\text { Universities }\end{array}$ & $\begin{array}{l}\text { Number of } \\
\text { Accredited } \\
\text { Universities }\end{array}$ & Percentage \\
\hline Central Universities & 50 & 35 & 70 \\
\hline State Universities & 409 & 131 & 32.03 \\
\hline Total & 459 & 166 & 36.2 \\
\hline
\end{tabular}

The percentage of accredited institutions under Revised Accreditation Framework during the study period (2017-2018) is more in the Categories of Central Universities. State Universities accredited so far constitute only one third of the total number of State Universities in the country.

\section{Region wise Analysis of the Performance of Central Universities}

NAAC has accredited 35 Universities out of the 50 universities. This constitutes $70 \%$ of the institutions. The data were analyzed region-wise and state-wise to identify the quality profile of the Central Universities across the country. The average CGPA for North East is 2.89. Assam, Manipur, Meghalaya, Mizoram have had a score of 3.01 and above. All the rest of the States have CGPA of below 3. All the six criteria for this region scored less than 3 except the criteria Infrastructure and Learning Resources, Student Support and Progression (C4 \& C5). Going through the details of the Analysis, the North East had covered 7 States: Arunachal Pradesh, Assam, Manipur, Meghalaya, Mizoram, Sikkim and Tripura.

Table 1: Average CGPA of Central Universities - North Eastern Region

\begin{tabular}{|l|c|c|c|c|c|c|c|c|}
\hline \multicolumn{1}{|c|}{ State } & $\begin{array}{c}\text { CGP } \\
\text { A }\end{array}$ & C1 & C2 & C3 & C4 & C5 & C6 & C7 \\
\hline Arunachal Pradesh & 2.4 & 2.67 & 2.7 & 2.16 & 2.5 & 2.6 & 1.8 & 2.3 \\
\hline Assam & 3.25 & 3 & 2.8 & 3.68 & 3.5 & 3.6 & 2.8 & 3.3 \\
\hline Manipur & 3.02 & 2.87 & 2.9 & 3.4 & 3 & 3.2 & 2.7 & 2.7 \\
\hline Meghalaya & 3.2 & 3.07 & 3.15 & 3.16 & 3.8 & 3.4 & 2.7 & 3.3 \\
\hline Mizoram & 3.16 & 2.97 & 3.24 & 2.75 & 3.8 & 2.59 & 3.63 & 3.66 \\
\hline Sikkim & 2.6 & 2.87 & 2.85 & 2.08 & 2.7 & 2.8 & 2.6 & 2.7 \\
\hline Tripura & 2.63 & 2.67 & 3.05 & 2.36 & 2.5 & 2.8 & 2.7 & 2.3 \\
\hline \multicolumn{1}{r|}{ AVERAGE } & $\mathbf{2 . 8 9}$ & $\mathbf{2 . 8 7}$ & $\mathbf{2 . 9 6}$ & $\mathbf{2 . 8}$ & $\mathbf{3 . 1 1}$ & $\mathbf{3}$ & $\mathbf{2 . 7}$ & $\mathbf{2 . 8 9}$ \\
\hline
\end{tabular}

Within the region, Assam, Manipur, Meghalaya and Mizoram have a score of 3.01 and above. Arunachal Pradesh, Sikkim and Tripura had less than three grade point average. Criterionwise, Infrastructure and Learning Resources scored high among the 7 criteria. The rest of the criteria scored less than 3 which is an average quality status.

\section{Eastern Region}

For the total Eastern Region, the Cumulative grade point average was only 2.69. Bihar had the highest score while Jharkhand and 
Odhisha had scored the lowest. It is observed that Universities scored higher CGPA in criteria 1 (i.e.) Curricular Aspects which is followed by Infrastructure and Learning Resources. The research quality is in lower level among the Universities in Eastern Region, which need to be taken care by the stakeholders.

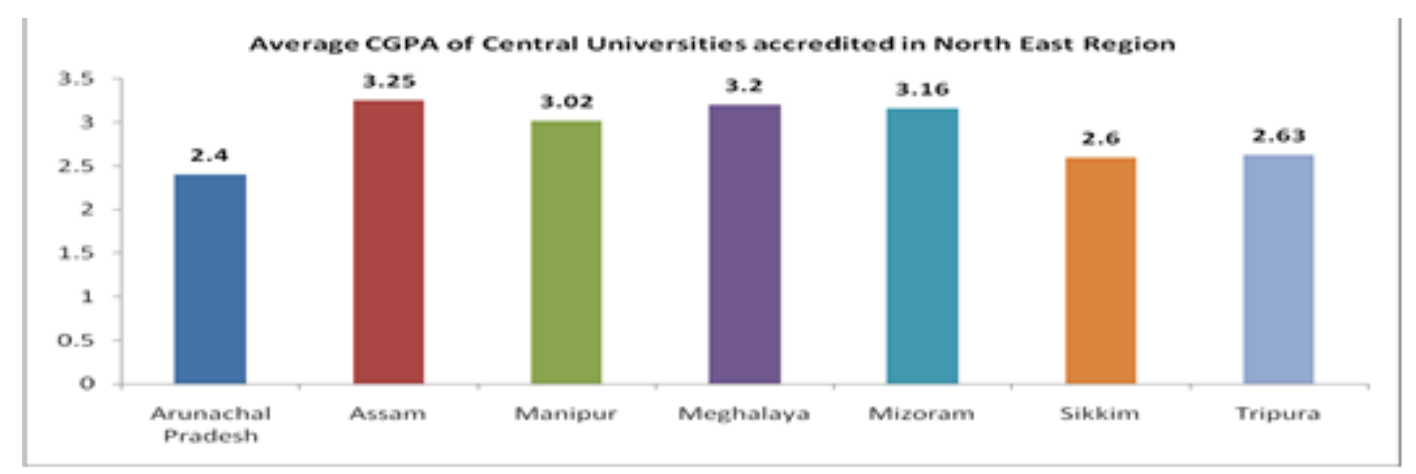

Table 2: Average CGPA of Central Universities-Eastern Region

\begin{tabular}{|l|c|c|c|c|c|c|c|c|}
\hline State & CGPA & C1 & C2 & C3 & C4 & C5 & C6 & C7 \\
\hline Bihar & 3.01 & 3.33 & 3 & 2.84 & 3.2 & 3 & 2.8 & 3 \\
\hline Jharkhand & 2.34 & 3.08 & 2.63 & 1.55 & 3.02 & 2 & 1.97 & 2.77 \\
\hline Odisha & 2.59 & 3.13 & 2.5 & 2.24 & 2.7 & 3 & 2.6 & 2.3 \\
\hline $\begin{array}{l}\text { West } \\
\text { Bengal }\end{array}$ & 2.82 & 2.87 & 2.75 & 2.92 & 2.4 & 2.6 & 2.8 & 3.3 \\
\hline AVERAGE & $\mathbf{2 . 6 9}$ & $\mathbf{3 . 1}$ & $\mathbf{2 . 7 2}$ & $\mathbf{2 . 3 9}$ & $\mathbf{2 . 8 3}$ & $\mathbf{2 . 6 5}$ & $\mathbf{2 . 5 4}$ & $\mathbf{2 . 8 4}$ \\
\hline
\end{tabular}

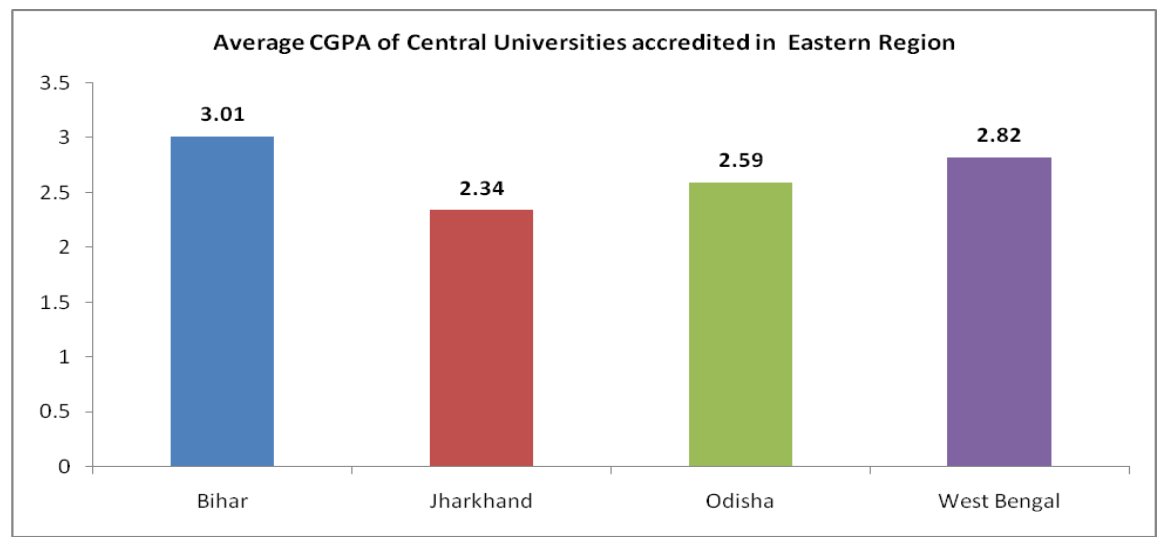

\section{Western Region}

Western region had an average of 2.92 . Maharashtra and Madhya Pradesh got the top score. On an average, curricular aspects and infrastructure facilities got a score above 3 and the rest are scoring less than 3. Among the Universities in Western region also shows the same trend prevailed as like Eastern region in terms of criterion score of Curricular Aspects, Infrastructure and Learning Resources ( $\mathrm{C} 1$ \& C4).The average CGPA for the organization management in Western is at lower level with 2.5 score, it reveals the Governance, Leadership, and Management is at average level. 
Table 3: Average CGPA of Central Universities-Western Region

\begin{tabular}{|l|c|c|c|c|c|c|c|c|}
\hline State & CGPA & C1 & C2 & C3 & C4 & C5 & C6 & C7 \\
\hline Gujarat & 2.76 & 3.27 & 3.1 & 2.28 & 3.2 & 2.6 & 2.3 & 2.7 \\
\hline $\begin{array}{l}\text { Madhya } \\
\text { Pradesh }\end{array}$ & 3.04 & 3.2 & 3 & 3.16 & 3 & 3 & 2.7 & 3 \\
\hline Maharashtra & 3.06 & 3.07 & 2.85 & 3.44 & 3.3 & 3 & 2.4 & 3 \\
\hline AVERAGE & $\mathbf{2 . 9 2}$ & $\mathbf{3 . 1}$ & $\mathbf{2 . 9 3}$ & $\mathbf{2 . 9 1}$ & $\mathbf{3 . 2}$ & $\mathbf{2 . 7 5}$ & $\mathbf{2 . 5}$ & $\mathbf{2 . 9 3}$ \\
\hline
\end{tabular}

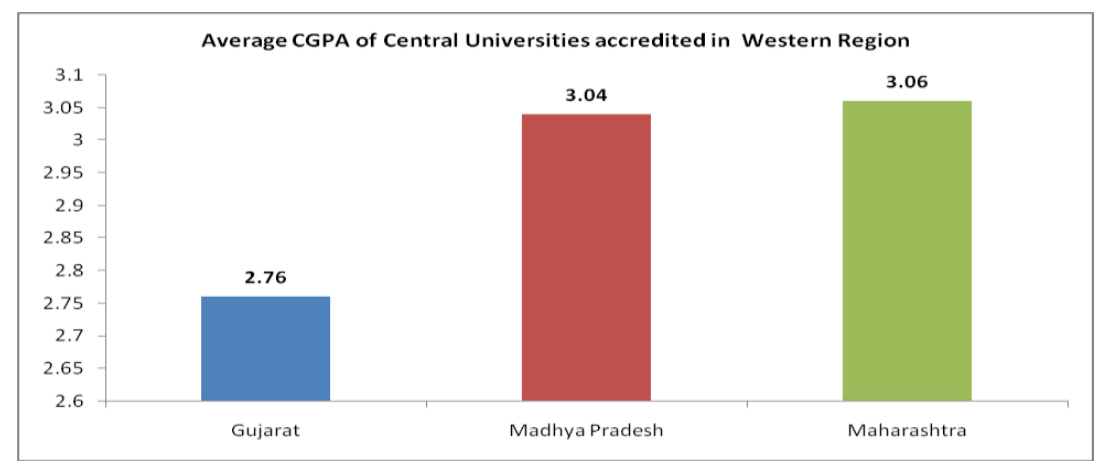

Maharashtra had the highest score followed by Madhya Pradesh. Gujarat scored lower score. This is mainly due to the deficit in research, Student support and progression and Governance and Leadership.

Northern Region
Northern region comparatively performed better with an average cumulative point of 3.04. Curricular Aspects, Teaching Learning and Evaluation and Infrastructure and Student support and Progression scored above 3 cumulative grade point average.

Table 4: Average CGPA of Central Universities in the Northern Region

\begin{tabular}{|l|c|c|c|c|c|c|c|c|}
\hline State & CGPA & C1 & C2 & C3 & C4 & C5 & C6 & C7 \\
\hline Delhi & 3.38 & 3.33 & 3.4 & 3.44 & 3.69 & 3.16 & 3.01 & 3.19 \\
\hline Haryana & 3.1 & 3.2 & 3.15 & 3 & 3 & 3 & 3.1 & 3.3 \\
\hline $\begin{array}{l}\text { Himachal } \\
\text { Pradesh }\end{array}$ & 2.78 & 3.33 & 2.95 & 2.72 & 2.5 & 2.6 & 2.7 & 2.3 \\
\hline $\begin{array}{l}\text { Jammu \& } \\
\text { Kashmir }\end{array}$ & 2.84 & 3.13 & 3.13 & 2.6 & 2.45 & 2.9 & 3.05 & 2.55 \\
\hline Punjab & 2.87 & 2.87 & 3.2 & 3 & 3.4 & 3.4 & 2.9 & 2.7 \\
\hline Rajasthan & 3.01 & 3.13 & 3.3 & 2.92 & 3 & 3.4 & 2.7 & 2.4 \\
\hline Uttarakhand & 3.11 & 3.33 & 3.1 & 2.92 & 3.5 & 3 & 3.1 & 3 \\
\hline Uttar Pradesh & 3.26 & 3.13 & 3.27 & 3.11 & 3.3 & 3.13 & 2.83 & 3.47 \\
\hline AVERAGE & $\mathbf{3 . 0 4}$ & $\mathbf{3 . 1 8}$ & $\mathbf{3 . 1 9}$ & $\mathbf{2 . 9 6}$ & $\mathbf{3 . 1 1}$ & $\mathbf{3 . 0 7}$ & $\mathbf{2 . 9 2}$ & $\mathbf{2 . 8 6}$ \\
\hline
\end{tabular}




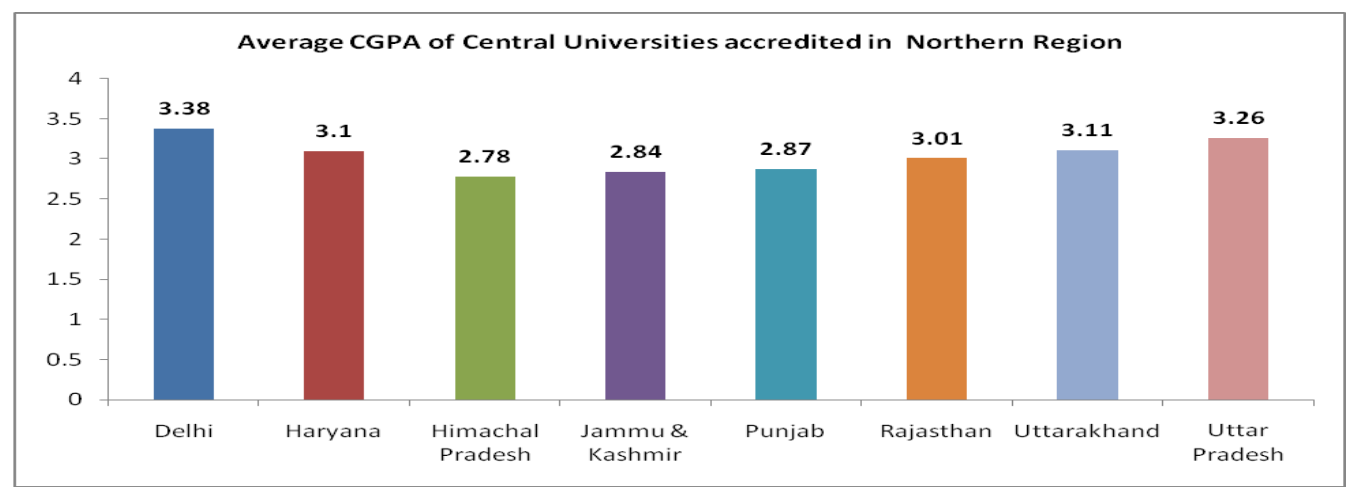

\section{Southern Region}

Southern region had a fairly good quality score. Telangana scored the highest with almost all scores of the seven criteria in the A grade category. This was followed by Pondicherry.

Table 5: Average CGPA of Central Universities in Southern Region

\begin{tabular}{|l|c|c|c|c|c|c|c|c|}
\hline State & CGPA & C1 & C2 & C3 & C4 & C5 & C6 & C7 \\
\hline Karnataka & 2.8 & 2.8 & 3 & 2.56 & 3 & 2.8 & 3 & 2.6 \\
\hline Kerala & 2.76 & 2.73 & 3.3 & 2.4 & 3 & 3.2 & 2.3 & 2.4 \\
\hline Puducherry & 3.1 & 3.47 & 3.53 & 2.35 & 3.8 & 3.15 & 2.53 & 3.31 \\
\hline Tamil Nadu & 2.78 & 2.8 & 3.3 & 2.6 & 2.5 & 3 & 2.9 & 2.7 \\
\hline Telangana & 3.36 & 3.6 & 3.4 & 3.44 & 3.37 & 3.07 & 3 & 3.33 \\
\hline AVERAGE & $\mathbf{3 . 0 7}$ & $\mathbf{3 . 2 3}$ & $\mathbf{3 . 3 3}$ & $\mathbf{2 . 8 9}$ & $\mathbf{3 . 2}$ & $\mathbf{3 . 0 5}$ & $\mathbf{2 . 8 2}$ & $\mathbf{3}$ \\
\hline
\end{tabular}

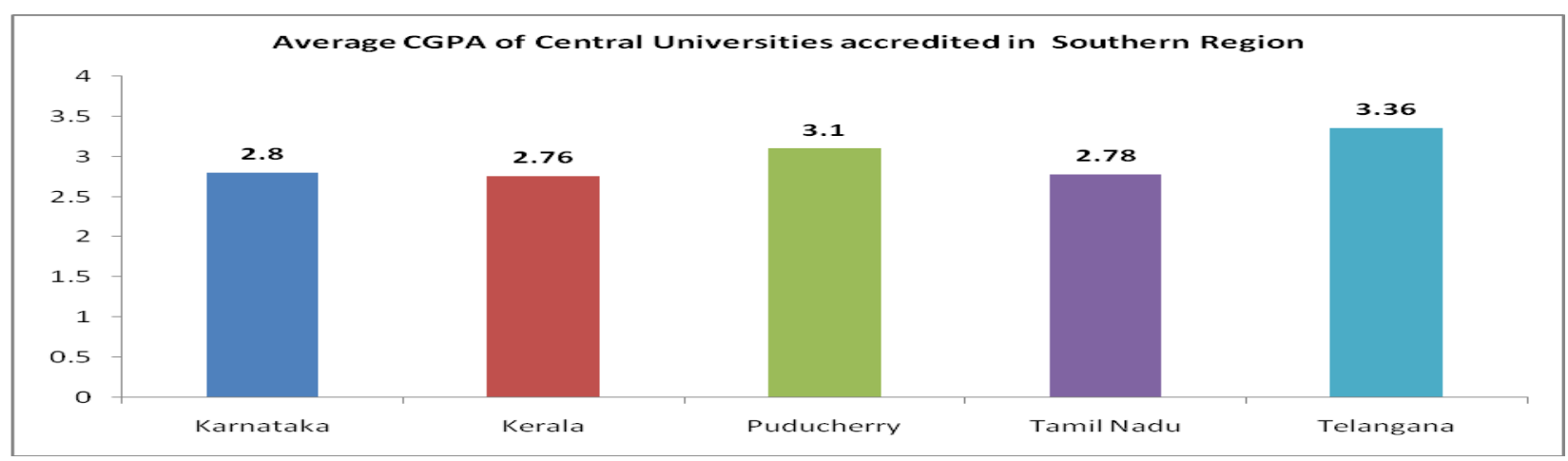

Table 6: Average CGPA of Central Universities-Region wise

\begin{tabular}{|l|c|c|c|c|c|c|c|c|}
\hline Region & CGPA & C1 & C2 & C3 & C4 & C5 & C6 & C7 \\
\hline South & 3.07 & 3.23 & 3.33 & 2.89 & 3.2 & 3.05 & 2.82 & 3 \\
\hline West & 2.92 & 3.1 & 2.93 & 2.91 & 3.2 & 2.75 & 2.5 & 2.93 \\
\hline North & 3.04 & 3.18 & 3.19 & 2.96 & 3.11 & 3.07 & 2.92 & 2.86 \\
\hline East & 2.69 & 3.1 & 2.72 & 2.39 & 2.83 & 2.65 & 2.54 & 2.84 \\
\hline $\begin{array}{l}\text { North- } \\
\text { East }\end{array}$ & 2.89 & 2.87 & 2.96 & 2.8 & 3.11 & 3 & 2.7 & 2.89 \\
\hline $\begin{array}{l}\text { All } \\
\text { India }\end{array}$ & $\mathbf{2 . 9 2}$ & $\mathbf{3 . 1}$ & $\mathbf{3 . 0 3}$ & $\mathbf{2 . 7 9}$ & $\mathbf{3 . 0 9}$ & $\mathbf{2 . 9}$ & $\mathbf{2 . 7}$ & $\mathbf{2 . 9}$ \\
\hline
\end{tabular}




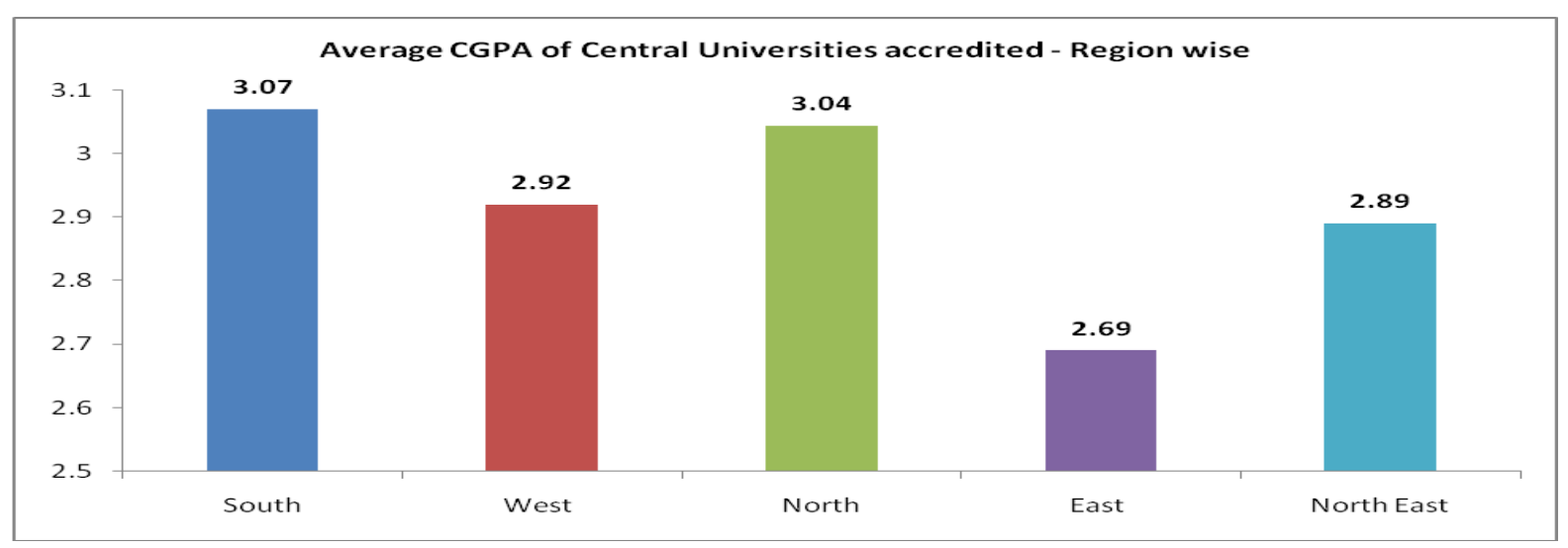

Within the regions, the ratings are as follows

Table 7 shows the Region wise Average CGPA Score of NAAC Accreditation

\begin{tabular}{|c|c|c|c|c|c|c|c|c|}
\hline \multicolumn{3}{|c|}{ SOUTHERN REGION (3.07) } & \multicolumn{3}{|c|}{ EASTERN REGION (2.69) } & \multicolumn{3}{|c|}{ WESTERN REGION (2.92) } \\
\hline S.N & State & CGPA & S.N & State & CGPA & S.N & State & CGPA \\
\hline 1 & Telengana & 3.36 & 1 & Bihar & 3.01 & 1 & Maharashtra & 3.06 \\
\hline 2 & Puducherry & 3.1 & 2 & West Bengal & 2.82 & 2 & Madhya Pradesh & 3.04 \\
\hline 3 & Karnataka & 2.8 & 3 & Odhisha & 2.59 & 3 & Gujarat & 2.76 \\
\hline 4 & Tamil Nadu & 2.78 & 4 & Jharkhand & 2.34 & & & \\
\hline 5 & Kerala & 2.76 & & & & & & \\
\hline
\end{tabular}

Table 7 (A) shows the Region wise CGPA Score

\begin{tabular}{|c|l|c|c|l|c|}
\hline \multicolumn{2}{|c|}{ NORTH EASTERN REGION (2.89) } & \multicolumn{3}{c|}{ NORTHERN REGION (3.04) } \\
\hline S.N & State & CGPA & S.N & State & CGPA \\
\hline 1 & Assam & 3.25 & 1 & Delhi & 3.38 \\
\hline 2 & Meghalaya & 3.2 & 2 & Uttar Pradesh & 3.26 \\
\hline 3 & Mizoram & 3.16 & 3 & Uttarkhand & 3.11 \\
\hline 4 & Manipur & 3.02 & 4 & Haryana & 3.1 \\
\hline 5 & Tripura & 2.63 & 5 & Rajasthan & 3.01 \\
\hline 6 & Sikkim & 2.6 & 6 & Punjab & 2.87 \\
\hline 7 & Arunachal Pradesh & 2.4 & 7 & Jammu \&Kashmir & 2.84 \\
\hline & & & 8 & Himachal Pradesh & 2.78 \\
\hline
\end{tabular}

It is observed that average CGPA for the five regions of the country, Southern region is dominant with 3.07, which is followed by North Eastern region Universities with average CGPA of 3.04. The performance of Universities is in the
Eastern region is low as per the RAF of NAAC accreditation. The CGPA for each State and the strong point in terms of criterion measures are given in the following table.

Table 8: State-wise CGPA and Strength point in terms of criterion measures

\begin{tabular}{|c|l|c|l|c|l|c|l|}
\hline SI.No & STATE & CGPA & STRENGTH & SI.No & STATE & CGPA & STRENGTH \\
\hline 1. & Delhi & 3.38 & Infrastructure & 13. & Rajasthan & 3.01 & Infrastructure \\
\hline
\end{tabular}




\begin{tabular}{|c|l|c|l|l|l|l|l|} 
2. & Telengana & 3.36 & All Criteria & 14. & Punjab & 2.87 & $\begin{array}{l}\text { Infrastructure, Student } \\
\text { Support }\end{array}$ \\
\hline 3. & Uttar Pradesh & 3.26 & $\begin{array}{l}\text { Institutional Values and } \\
\text { Best practices }\end{array}$ & 15. & $\begin{array}{l}\text { Jammu \& } \\
\text { Kashmir }\end{array}$ & 2.84 & $\begin{array}{l}\text { Curricular Aspects, } \\
\text { Teaching \& Learning }\end{array}$ \\
\hline 4. & Assam & 3.25 & Research \& Infrastructure & 16. & West Bengal & 2.82 & Research, Innovation \\
\hline 5. & Meghalaya & 3.2 & Infrastructure & 17. & $\begin{array}{l}\text { Himachal } \\
\text { Pradesh }\end{array}$ & 2.78 & Curricular Aspects \\
\hline 6. & Mizoram & 3.16 & Infrastructure & 18. & Gujarat & 2.76 & Curricular Aspects \\
\hline 7. & Uttarkhand & 3.11 & Curricular Aspects & 19. & Tripura & 2.63 & Teaching Learning \\
\hline 8. & Haryana & 3.1 & $\begin{array}{l}\text { Innovation \& Best } \\
\text { Practices }\end{array}$ & 20. & Sikkim & 2.6 & Curricular Aspects \\
\hline 9. & Puducherry & 3.1 & $\begin{array}{l}\text { Curricular Aspects } \\
\text { \&Teaching }\end{array}$ & 21. & Odhisha & 2.59 & Curricular Aspects \\
\hline 10. & Maharashtra & 3.06 & Infrastructure & 22. & $\begin{array}{l}\text { Arunachal } \\
\text { Pradesh }\end{array}$ & 2.5 & Infrastructure \\
\hline 11. & Madhya Pradesh & 3.04 & Infrastructure & 23. & Jharkhand & 2.34 & Curricular Aspects \\
\hline 12. & Bihar & 3.01 & Curricular Aspects & & & & \\
\hline
\end{tabular}

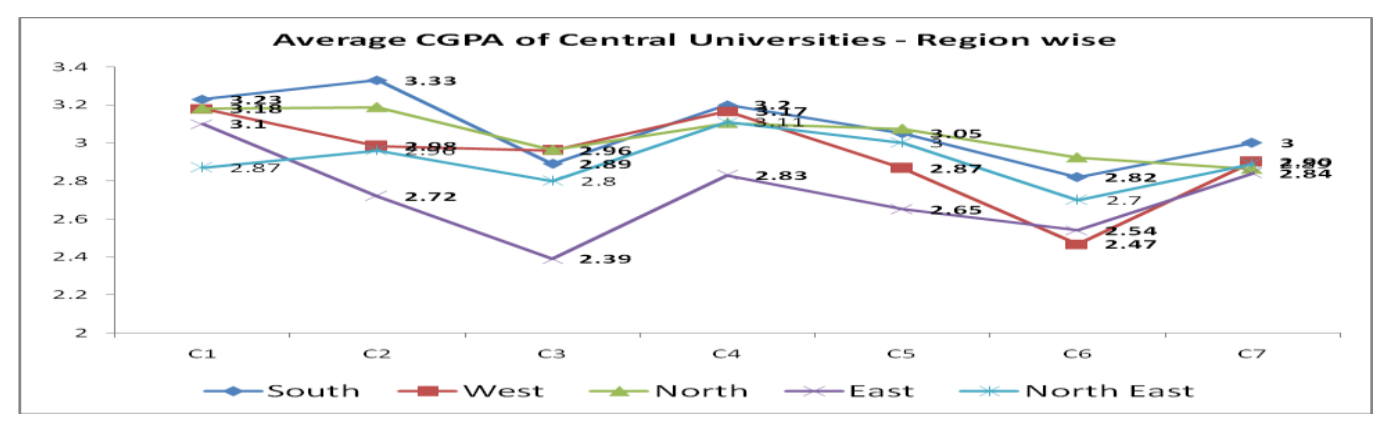

Performance Analysis of State Universities.

There are 409 State Universities distributed over the different states. Uttar Pradesh, Gujarat, Karnataka, West Bengal and Maharashtra have large number of State Universities. They offer quality education to students at affordable cost.

Table 9: Distribution of State Universities in India

\begin{tabular}{|c|l|c|c|l|c|}
\hline Sl. No & State & Number & Sl. No & State & Number \\
\hline 1. & Andhra Pradesh & 20 & 14. & Maharashtra & 23 \\
\hline 2. & Assam & 12 & 15. & Manipur & 1 \\
\hline 3. & Bihar & 15 & 16. & Odhisha & 16 \\
\hline 4. & Chhattisgarh & 13 & 17. & Punjab & 9 \\
\hline 5. & Goa & 1 & 18. & Rajasthan & 22 \\
\hline 6. & Gujarat & 28 & 19. & Tamil Nadu & 22 \\
\hline 7. & Haryana & 14 & 20. & Telangana & 16 \\
\hline 8. & Himachal Pradesh & 9 & 21. & Tripura & 1 \\
\hline 9. & Jammu \&Kashmir & 8 & 23. & Uttar Pradesh & 30 \\
\hline 10. & Jharkhand & 27 & 24. & West Bengal & 11 \\
\hline 11. & Karnataka & 13 & 25. & NCT of Delhi & 7 \\
\hline 12. & Kerala & &
\end{tabular}




\begin{tabular}{|c|l|c|c|l|c|}
\hline 13. & Madhya Pradesh & 21 & 26. & Chandigarh & 1 \\
\hline
\end{tabular}

State Universities have affiliated colleges and have the responsibilities to monitor the colleges affiliated to them. The scores of the State Universities are given below:

\begin{tabular}{|c|c|c|}
\hline CGPA Range & $\begin{array}{c}\text { Number of State } \\
\text { Universities }\end{array}$ & Percentage \\
\hline $1.51-2.00$ & 7 & 5 \\
\hline $2.01-2.50$ & 18 & 14 \\
\hline $2.51-2.75$ & 17 & 13 \\
\hline $2.76-3.00$ & 17 & 13 \\
\hline $3.01-3.25$ & 51 & 39 \\
\hline $3.26-3.50$ & 11 & 8 \\
\hline $3.51-4.00$ & 10 & 8 \\
\hline Total & $\mathbf{1 3 1}$ & $\mathbf{1 0 0}$ \\
\hline
\end{tabular}

It is found from the data that majority of the State Universities of accreditation, Universities performed very well with the higher score of 3 and above, while $26 \%$ of accreditation State Universities performed average and above average and obtained score between 2.51-3.00. Criterion wise NAAC accreditation score of State Universities would reveal than University of Punjab were dominant in terms of Curricular Aspects with average CGPA of 3.34 , which is followed by Delhi (3.28) and Haryana (3.11).

Table 10: Average CGPA of State Universities accredited (State wise and Criteria wise)

\begin{tabular}{|c|l|l|c|c|c|c|c|c|c|c|}
\hline $\begin{array}{c}\text { Sl. } \\
\text { No }\end{array}$ & State & Region & CGPA & C1 & C2 & C3 & C4 & C5 & C6 & C7 \\
\hline 1 & Andhra Pradesh & South & 2.9 & 3.19 & 3.05 & 2.68 & 2.93 & 2.73 & 2.66 & 3.02 \\
\hline 2 & Assam & North East & 2.87 & 2.95 & 3.03 & 2.66 & 3.05 & 2.86 & 2.71 & 2.86 \\
\hline 3 & Bihar & East & 2.48 & 2.71 & 2.88 & 2.08 & 2.72 & 2.47 & 2.21 & 2.37 \\
\hline 4 & Chhattisgarh & East & 2.39 & 2.95 & 2.47 & 1.78 & 2.97 & 2.17 & 2.46 & 2.46 \\
\hline 5 & Delhi & North & 3.28 & 3.4 & 3.38 & 3.3 & 3.57 & 3.14 & 2.59 & 3.4 \\
\hline 6 & Gujarat & West & 2.94 & 3 & 2.92 & 2.79 & 3.12 & 2.94 & 2.92 & 3.06 \\
\hline 7 & Haryana & North & 3.11 & 3.07 & 3.19 & 2.98 & 3.35 & 3.41 & 2.99 & 2.93 \\
\hline 8 & Himachal Pradesh & North & 2.87 & 2.95 & 3.03 & 2.66 & 3.05 & 2.86 & 2.71 & 2.86 \\
\hline 9 & Jammu \& Kashmir & North & 3.11 & 3.34 & 3.21 & 2.95 & 3.46 & 2.91 & 2.97 & 2.97 \\
\hline 10 & Jharkhand & East & 2.2 & 2.29 & 2.74 & 1.57 & 2.26 & 2.46 & 2.06 & 2.3 \\
\hline 11 & Karnataka & South & 2.86 & 2.96 & 3.15 & 2.52 & 3.26 & 2.75 & 2.67 & 2.78 \\
\hline 12 & Kerala & South & 2.94 & 2.85 & 2.94 & 2.9 & 3.1 & 2.92 & 2.74 & 3.2 \\
\hline 13 & Madhya Pradesh & West & 2.88 & 2.99 & 2.97 & 2.7 & 3.02 & 3.03 & 2.85 & 2.7 \\
\hline 14 & Maharashtra & West & 2.99 & 2.95 & 3.07 & 2.88 & 2.94 & 3.17 & 2.94 & 2.94 \\
\hline 15 & Odhisha & East & 2.95 & 2.84 & 3.2 & 2.83 & 2.92 & 3.09 & 2.98 & 2.72 \\
\hline 16 & Punjab & North & 3.34 & 3.42 & 3.23 & 3.21 & 3.83 & 3.47 & 3.03 & 3.4 \\
\hline 17 & Rajasthan & North & 2.71 & 2.58 & 2.72 & 2.92 & 2.97 & 2.6 & 2.6 & 2.3 \\
\hline
\end{tabular}




\begin{tabular}{|l|l|l|c|c|c|c|c|c|c|c|}
\hline 18 & Tamil Nadu & South & 3.02 & 3.19 & 3.19 & 2.93 & 3.14 & 2.98 & 2.75 & 2.75 \\
\hline 19 & Telangana & South & 2.78 & 3.13 & 3.03 & 2.3 & 2.99 & 2.72 & 2.51 & 3.03 \\
\hline 20 & Uttar Pradesh & North & 2.56 & 2.59 & 2.77 & 2.3 & 2.85 & 2.44 & 2.34 & 2.74 \\
\hline 21 & Uttarakhand & North & 2.55 & 2.56 & 3 & 2.14 & 2.87 & 2.09 & 2.44 & 2.83 \\
\hline 22 & West Bengal & East & 2.93 & 2.88 & 3.12 & 2.74 & 3.1 & 2.92 & 2.74 & 3.05 \\
\hline & All India & & $\mathbf{3 . 1 1}$ & $\mathbf{3 . 3 4}$ & $\mathbf{3 . 2 1}$ & $\mathbf{2 . 9 5}$ & $\mathbf{3 . 4 6}$ & $\mathbf{2 . 9 1}$ & $\mathbf{2 . 9 7}$ & $\mathbf{2 . 9 7}$ \\
\hline
\end{tabular}

Table 11: Average CGPA of State Universities - Region wise

\begin{tabular}{|c|l|c|c|c|c|c|c|c|c|}
\hline Sl. No. & Region & C1 & C2 & C3 & C4 & C5 & C6 & C7 & CGPA \\
\hline 1 & South & 3.06 & 3.07 & 2.67 & 3.08 & 2.82 & 2.66 & 2.96 & 2.90 \\
\hline 2 & West & 2.98 & 2.99 & 2.79 & 3.03 & 3.05 & 2.90 & 2.90 & 2.93 \\
\hline 3 & North & 2.99 & 3.07 & 2.81 & 3.24 & 2.87 & 2.71 & 2.93 & 2.94 \\
\hline 4 & East & 2.73 & 2.88 & 2.20 & 2.79 & 2.62 & 2.49 & 2.58 & 2.59 \\
\hline 5 & North East & 2.95 & 3.03 & 2.66 & 3.05 & 2.86 & 2.71 & 2.86 & 2.87 \\
\hline & All India & $\mathbf{2 . 9 4}$ & $\mathbf{3 . 0 1}$ & $\mathbf{2 . 6 3}$ & $\mathbf{3 . 0 4}$ & $\mathbf{2 . 8 4}$ & $\mathbf{2 . 6 9}$ & $\mathbf{2 . 8 5}$ & $\mathbf{2 . 8 5}$ \\
\hline
\end{tabular}

It would reveal from the analysis that among the State Universities, Northern region have got higher score of CGPA (2.94), which is followed by Western region (2.93) and Southern region (2.90).In general observation is that the accredited State Universities are didn't performing well. Since no region would acquire the CGPA of 3.0 and all India CGPA is 2.85, it shows the dissimilarities among the Universities in terms of performance quality with regard to all criterion. It is quiet surprise to know that the average CGPA of Research, Consultancy, and Extensions (3) is very much low with 2.65 compare by with other criteria. Being the Universities, they need to make emphasize on enhancing the quality of research.

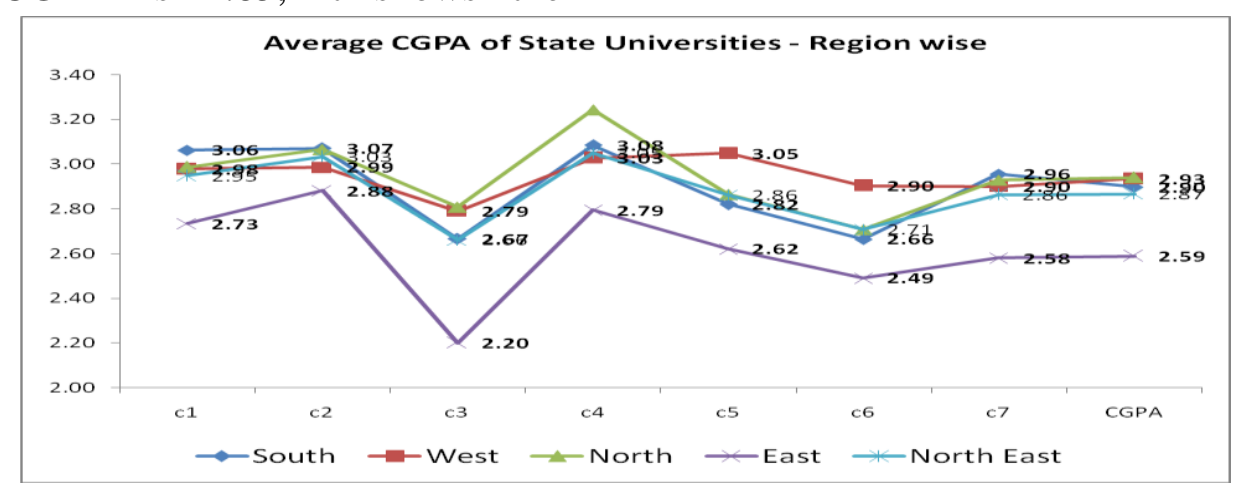

A summary of the Quality Status of the different types of Universities are given below:-

Table 12: Quality Status of different Universities:

\begin{tabular}{|l|l|l|l|l|l|l|l|l|}
\hline $\begin{array}{c}\text { Type of } \\
\text { University }\end{array}$ & CGPA & C1 & C2 & C3 & C4 & C5 & C6 & C7 \\
\hline Central & 2.92 & 3.10 & 3.03 & 2.79 & 3.09 & 2.90 & 2.70 & 2.90 \\
\hline State & 2.84 & 3.34 & 3.21 & 2.95 & 3.46 & 2.91 & 2.97 & 2.97 \\
\hline
\end{tabular}

Among the different types of Universities, Central Universities which has faire well and is approaching the CGPA of 3. Among all the criteria, Research,Innovation and Extension got the lowest score for all types of institutions. Even for the global ranking, india got the least score for this criterion. 


\section{Conclusion}

The overall Quality Grade points for the institutions and criterion-wise grade points were also compared in this analysis. It is observed that when the institutions are reaccredited, they have improved their quality score significantly. In North Eastern, there are regional variations and also state-wise variations for the overall score as well as for each of the Quality criteria. . Criterion wise, Infrastructure and Learning resources have the highest score which are the visible quality goals for an Institution. The grades obtained in the various cycles of assessment are not significantly different, which indicates the lack of effort on the part of the institutions to improve the quality of education imparted through the quality improvement processes. In the Eastern Region, the criterion curricular aspects scored high, while all the rest of the criteria scored much lower scores which means the significant gap need to be rectified for all other criteria to achieve a desirable level of quality. Criterion 1 scored 3.33, Teaching, learning, Evaluation and the Innovative practices scored lower scores. In Western Region, here again, Teaching, Learning and Evaluation, Student support and Progression, Governance and Leadership has to be improved. Gujarat and Madhya Pradesh and Maharashtra scored high in curricular aspects. In case of Infrastructure facilities all the states scored well, including the $7^{\text {th }}$ criteria- Institutional Values and best practices. In Northern Region, research and Goverance has scored low. Among the States, Delhi scored the highest. Higher Education Institutions in Delhi had performed good in all the criteria. This was followed by UttarPradesh,Uttarkhand and Haryana. Himachal Pradesh, Jammu \&Kashmir and Punjab need to focus on all aspects of quality criteria. Analysis of State and Central Universities by CGPA Regionwise, Southern region scored the highest and the other regions are in the second level of B grade. Region wise, the percentage of accreditation (according to university wise is lowest for Eastern Region i.e. $36 \%$ with $64 \%$ need to be accredited yet. Highest is for North Eastern Region with 54\% percent accredited and $46 \%$ yet to be accredited. Southern Region comes next with 52 percent accredited and 48 percent yet to be accredited. In the college sector $7 \%$ of the colleges are accredited from the Eastern Region with $93 \%$ yet to be accredited. The highest is from Western Region constituting 57\% and next is from North Eastern region $43 \%$. The largest share of accredited institution is from Western and Northeastern region. In general, the response from the university sector is better compared to that from the college sector.

\section{Recommendations}

$>$ Changing the Management system of excessive government control over the Higher Education Institutions.

$>$ Expand the powers of decision making of the institutions to enable the development of their initiatives and ability to meet the needs of economic and social development.

$>$ Participative Management, Decentralization, Capacity Building of all the team members are essential for institution to take initiative and make the institutions successful and sustainable.

$>$ Central/UGC/State Governments must draw up enabling policies signifying the importance of financial support to meet capacity needs, to meet emerging and growing costs especially in terms of infrastructure and highly qualified Faculty to be able to achieve the noble mission of institutions.

$>$ Fee enhancement/ Differential fee structure. Policies have to be laid out for performance funding, credit transfer, fee for student exchange programs.

$>$ Institutions should be able to establish academic linkages with reputed national/international organizations for enhancing the quality of curricular offering, teaching-learning, ICT 
integration, staff development programs and research activities.

Universities need to have a meaningful, relevance and stringent and consistence perform appraisal of the faculty members to bridge the gap.

\section{References}

[1] Amutha, S., \& Ponmudiraj, B. S. (2019). A Symbiotic Analysis of NAAC Accredited Higher Education Institutions. Journal of the Gujarat Research Society, 21(4), 57-69.

[2] Mukhopadhyay, P., Tapaswi, M. P., Sudarsan, P. K., \& Sudarsan, K. (2018) Assessing The Quality of Higher Education Institutions in India: An Alternative Framework.

[3] www.naac.gov.in

[4] http://www.naac.gov.in/resources/publicatio ns/manuals

[5] http://naac.gov.in/docs/Books/Accreditation -Outcome.pdf

[6] https://assessmentonline.naac.gov.in/public/i ndex.php/hei_public_dashboard

[7] https://www.youtube.com/watch?v=HCyLz bsyaik

[8] https://journals.plos.org/plosone/article/file? $\mathrm{id}=10.1371 /$ journal.pone $.0239140 \&$ type $=$ pri ntable 